\title{
THE EFFECTIVENESS OF DEBATE TECHNIQUE TOWARD THE STUDENTS' CONFIDENCE IN SPEAKING SKILL AT XI GRADE OF SMKN 2 TEMBILAHAN
}

\author{
Lorika Malasari*1, Sri Erma Purwanti*2 \\ lorika.malasari@gmail.com ${ }^{* 1}$, sri88erma@gmail.com ${ }^{* 2}$ \\ English Education Department \\ Islamic University of Indragiri - Tembilahan
}

\begin{abstract}
Confidence is an important thing in speaking because without it speaking skill can not be well and it became one of some problems in speaking skill which faced by the students of SMK Negeri 2 Tembilahan. To solve the problem, the reseacher conducted the experimental research is that quasy experimental design by applying the debate technique. The aim of this research is to know the effectiveness of debate technique on students' confidence in speaking skill. The data collection technique in this research is questionnaire that consists of 20 Close Ended statements using Likert Scale type. The sample of this research is 33 students of XI grade of SMK Negeri 2 Tembilahan as control and experimental class. After getting the data using questionnaire, the reseacher find that debate technique is effective toward students' confidence in speaking skill with the result $t$-observed is 15,84 while $t$-table is 2,04 from $5 \%$ and 2,75 from $1 \%$. The $t$ observed score is higher than t-table. Based on the result, $\mathrm{H} 0$ (null hypothesis) is rejected and $\mathrm{Ha}$ (alternative hypothesis) is accepted. It also means that debate technique is effective toward students' confidence in speaking skill at XI grad of SMK Negeri 2 Tembilahan in academic years 2017/2018.
\end{abstract}

Keywords: Debate Technique, Students' Confidence, Speaking Skill.

\section{INTRODUCTION}

In learning English, many students understand the explanation or what the teacher say to them but they cannot respond. It happens because of many factors such as anxiety, low confidence, their thought that speaking English not important, being shy, and the environment that not support them to speak English, and etc. though we know English is an International language that exactly will be used in learning or communicate with other people from other countries.

In curriculum 2013, the students should be more active and their teacher just be a supervisor. The method which is commonly used in this curriculum is discussion. According to Schwarthz (2013: 1) adds "discussion is an effective way to facilitate learning with an opportunity to assess student understanding of course material by introducing their own observations and questions, students can explore ideas thoroughly". But this technique is less effective at this school that affected by the problems above. 


\section{Lorika Malasari $^{* 1}$, Sri Erma Purwanti ${ }^{* 2}$ \\ THE EFFECTIVENESS OF DEBATE TECHNIQUE \\ TOWARD THE STUDENTS' CONFIDENCE IN SPEAKING SKILL \\ AT XI GRADE OF SMKN 2 TEMBILAHAN}

Following the explanation above, the reseacher decided to apply debate technique to solve the students' problem. Rose (2011: 2 in Astin Ryoko, 2015: 3) adds "Debate activity is very successful teaching technique which facilitates learning in a depth as the students' research and weight evidence within and across different subject and topic, learn to distinguish facts from opinions, and present well considered arguments". So, debate can help the students to speak with present their arguments on an issue. This research focuses on students' confidence problem in speaking skill that applies debate technique to solve it.

There are some researchers that conducted the same research but just focused on improving speaking skill and oral communication ability. The first research by Uswatun Hasanah (2012) entitled "The Implementation of Debate Technique to Improve Students' Speaking Skill (Classroom Action Research at the Second Year of MTs SA Miftahul HudaPabelan, Semarang Regency 2011/2012", English Department Of Educational Faculty of State Islamic Studies Institute (STAIN), Salatiga. The result of this research debate can be found that debate technique has benefit to improve students speaking competence in class and encorage students confidence.

The second reseach by Pezhman Zare and Moomala Othman (2014) is that "Students' Perceptions toward Using Classroom Debate to Develop Critical Thinking and Oral Communication Ability", Department of Language and Humanities Education, Faculty of Educational Studies, Universiti Putra Malaysia, Selangor, Malaysia. In addition, the result is the students claimed, other benefits of the debates included mastering the course content, boosting confidence, overcoming the stage fright, and improving team work skills.

It is different with the researchers above that discuss the improvement on students' speaking skill, the writers of this research focus on the students' confidence in speaking skill.

\section{LITERATURE REVIEW}

\section{Speaking Skill}

Speaking is a productive skill in the oral mode. It is more complicated than it seems at first and involves more than just pronouncing words. According to Brown (2004: 140) and Harmer (2007: 123) speaking is a productive skill that used to communicate directly with apply various elements of language. To express their ideas or arguments, everyone can speak and use elements of language to deliver clear and understandable information.

Speaking skills give the speakers an ability to have verbal interaction effectively. They allow them to convey messages in passionate, thoughtful and convincing manner. They also help to assure that one won't be misunderstood by those who are listening.

\section{Debate Technique}

Harmer (2002: 271-275) said that there are some speaking activities that are commonly used in the classroom and one of them is Debate. Debate is one of some technique that used to communicate. According to Ericson, Murphy and Zeuschaner (2003: 1), Akerman and Neale (2011: 9) and Nally (2015) who gave 
definition of debate technique. Based on the some experts above it can be summarize that debate technique is a technique which used in an activity where two speakers or more be in contradiction share opinion one of another. This can be educational tool that used in teaching speaking for students to develop students' confidence in speaking English since it allows students to share and cooperate well with one another.

\section{Advantages of Debate Technique}

There are some advantages by using debate as the technique of teaching Speaking, as follow:

a) Debate allow students to share and cooperate well with one other,

b) It educates the students' about responsibility,

c) Encorages creatifity,

d) Deepens friendship and build rapport with the teachers,

e) Students are motivated and enjoy the activity,

f) It can improve students' speaking skill

g) To produce conversation, With the smaller context of debate, students can become more lively and gain more confidence (Buckley (2008) in Somjai and Jansem (2005: 28).

2. Procedures of Debate

Rubiati (2010:19) states that the form of debate is varied in use. In speaking classroom, debate can be taken such as the following procedures:

a) Dividing the students into many groups. Each group consists of 3 students.

b) Selecting debate topic and assigning the groups to debate topic.

c) Ensuring that the participants have time beforehand to prepare for the arguments and to collect supporting data to present during the debate.

d) Presenting the topic and format the debate.

3. Types of Debate

There are four types of debates that are commonly used, they are:

a) The Lincoln-Douglas type of debate is a kind of debate where there is only one speaker in the side of the affirmative as well as in the side of the negative. The speaker is in the affirmative side opens the debate then followed by the negative speech.

b) The Rebuttal Type of debate is a kind of debate where each team from the affirmative and the negative side is composed of about two or three members. As the debate starts, the affirmative speaker opens the constructive speech and the negative speaker starts the rebuttal. Every speaker is allowed to deliver a rebuttal speech. The debate is closed with the affirmative side delivering the last rebuttal.

c) The One-Rebuttal type of debate is considered as a modified form of the Lincoln-Douglas type of debate. However in this type of debate, there are about two or three members in both the affirmative and the negative side. In this type, all of the speakers have a chance to refute the argument of the opponent with the exception of the first affirmative speaker who is given the opportunity to close the debate in his or her rebuttal speech. 
Lorika Malasari $^{* 1}$, Sri Erma Purwanti ${ }^{2}$

THE EFFECTIVENESS OF DEBATE TECHNIQUE

TOWARD THE STUDENTS' CONFIDENCE IN SPEAKING SKILL

AT XI GRADE OF SMKN 2 TEMBILAHAN

d) The Oregon-Oxford type of debate also allows two or three speakers in both the affirmative and the negative side. In this type, the first speaker in the affirmative side delivers the entire affirmative case. After the delivery, the first affirmative speaker will be interpellated by the first speaker of the negative side. After this, the second speaker of the negative side will present the entire negative case; then the second negative speaker will be interpellated by the second or the first affirmative speaker. After the first speaker of the negative will deliver his or her rebuttal speech followed by the rebuttal of the second affirmative speaker (Varron, 2016).

\section{Confidence}

Confidence is the most listened term that well-known as an individual's trust in his or her own abilities, capacities, and judgments, or belief that he or she can do a challenge successfully. In line with the previous, Yates and Chisari (2013:1) said "Confidence describes a mental attitude that focuses on trust and reliance on oneself and often includes notions of self-assurance, boldness, and fearlessness. For ESL learners, it is defined as form of self-reliance on oneself and is often linked to self-esteem and motivation". Another definition based on the Wesson (2005), confidence can be divided as having a firm trust on one's ability, having a sense of reliance or certainly.

There are some indicators of confidance based on the Burton and Platts (2006: 13):

a. Having a direction in life and know the value of her/himself

b. Being motivated by and enjoying in doing something

c. Having good emotional stability; calm and focused.

d. Having an ability to stay optimistic

e. Knowing her/his capability

f. Getting easy to adapt in certain circumstances

g. Loving to develop knowledge or insight

h. Having a sense to manage stressful situation

i. Having a willingness to take risk

j. Having a sense of purpose

\section{METHODOLOGY}

\section{Research Design}

In this research, researcher used Quasi Experimental research design that be supported by quantitative approach based on Frankle and Wallen (2003: 268) and Sugiono (2010;114). This method was design by giving pre-test before the treatment and post-test after the treatment. The treatment was only given to the experimental group.

There were nine classes of tenth grade there with total 287 students as the population and 33 as the sample taken by purposive sampling technique. There were 15 students in control group and 18 students in experimental group. 


\section{Instruments}

To get specific information or data of the effectiveness of debate technique on students' self-confidence, researcher used questionnaire as the instrument. There were 20 close ended statements using Likert Scale Type.

\section{Research Procedure}

1. Experimental group

a) Pre test

Pre test was given to experimental group where was in first meeting. In this meeting, the reseacher as a teacher asked the students to search information about analytical exposition that be the matter. After it, students showed up or presented their assignment in front of the class. After all, the reseacher gave questionnaire to the students.

b) Treatment

After pre test, in the second meeting reseacher explained about debate such as the procedure, rules and scoring. After that, the reseacher divided the students into two groups; positive and negative team into some round. The reseacher divided debate position and gave motion (topic) using analytical exposition text. Students were given 15 minutes to build idea (case building) by researcher. After it, the students had oral presentation individually based on the motion that they got. The students debated motion in each round (2 round) so other students stayed as audience while one round having debate.

c) Post test

Post test was given by reseacher after the treatment (apply debate technique in last meeting) by giving last questionnaire for students.

\section{Control Group}

a) Pre test

Pre test was given to control group where was given in first meeting. In this meeting, the reseacher as a teacher asked students to search information about analytical exposition that be in the metter. After it, students should showed up or presented their assignment in front of the class. After all, the reseacher gave questionnaire to students.

b) Applying conventional technique

The reseacher came in the class, told them about what they will do and gave material or topic for students. After it, reseacher asked the students to make group to discuss the topic and presented the disscussion results in the class. The reseacher as a teacher gave question and answer section in the discussion to show up students' speaking.

c) Post test 


\section{Lorika Malasari $^{* 1}$, Sri Erma Purwanti ${ }^{* 2}$ \\ THE EFFECTIVENESS OF DEBATE TECHNIQUE \\ TOWARD THE STUDENTS' CONFIDENCE IN SPEAKING SKILL \\ AT XI GRADE OF SMKN 2 TEMBILAHAN}

Post test was conducted in the last meeting. The procedure used was the same in the pre-test where students were given material and they discussed the topic after it the reseacher gave questionnaire to the students to get the last data.

After collecting the data, the result of questionnaire (pre and post) was analyzed using statistical analysis in order to find out the effectiveness of debate technique toward students' confidence in speaking skill. The data was analyzed by following method which mentioned by Hatach and Farhady (1982: 55) where there were some steps that should be done based on the experimental research; Determine the Mean of Both Groups (Experimental and Control); Determine the Deviation Standard (DS) of both Groups (Experimental and Control); Determine Standard Error of Different between the Means in both groups (Experimental and Control); Determine t-observed; Determine Degree of Freedom (DF); Test Hypothesis.

\section{FINDINGS}

Based on the experiment statistical analysis, it could be observed that in pre questionnire, the students of control and experimental class were not confident in speaking skill, the result as bellow:

t-observerd $=-0,12 \quad$ t-table $5 \%=2,04$

$$
1 \%=2,75
$$

The result, $\mathrm{Ho}$ is accepted and $\mathrm{H}_{1}$ is rejected. It means that there is no difference between students' confidence of experimental class and students' confidence of control class before having treatment. It also means, the students of SMK Negeri 2 Tembilahan especially in IX grade were not confident in speaking skill.

After giving the treatment in experimental class and conventional technique in control class, the researcher conducted post questionnaire. And the result of post questionnaire analysis was:

t-observerd $=15,84 \quad$ t-table $5 \%=2,04$

$$
1 \%=2,75
$$

The result, Ho is rejected and $\mathrm{H}_{1}$ is accepted. It means that there is the significant effect of the implementation of debate technique toward students' confidence in speaking skill at XI grade of SMK Negeri 2 Tembilahan. It also means the students of SMK Negeri 2 Tembilahan were confident in speaking skill using debate.

\section{CONCLUSION}

As we know debate is one of some techinques that can be used in teaching speaking because using the techinque, students can give their arguments to show up their speaking skill. Confidence is full trust of believe of someone. To know the effectiveness of debate technique toward students confidence in speaking skill, the reseacher conducted the research. After conducting the research in SMK Negeri 2 Tembilahan, the reseacher found that t-observed is higher than table $(15,84 \geq 2,04$ or $15,84 \geq 2,74)$ at the level of significant $5 \%$ or $1 \%$ with the degree of freedom $(\mathrm{df})=31$. It means that null hypothesis is rejected $\left(\mathrm{H}_{0}\right)$ and the alternative hypothesis $\left(\mathrm{H}_{1}\right)$ is accepted. It also means that debate technique was 
effecteive toward students' confidence in speaking skill that studying analytical exposition text to XI grade studets of SMK negeri 2 Tembilahan.

Based on the information above, it can be concluded that implementation of debate technique toward students' confidence in speaking skill was applied well, it was showed in statistical analysis.

\section{REFERENCES}

Akerman, R., \& Neale, I. (2011). Debating the Evidence. Reading, RG: CfBT Education Trust.

Brown, H. D. (2004). Language Assesment: Principles and Classroom Practise. New York: Pearson Education.

Burton, K \& Platts, B. (2006). Building Confidence for Dummies®. John Wiley \& Sons, Ltd. England.

Fraenkel, J. R. \& Wallen, N. E. (2003). How to Design and Evaluate Research in Education Fifth Edition. New York: McGraw-Hill.

Hasanah, U. (2012). The Implementation of Debate Technique to Improve Students' Speaking Skill (Classroom Action Research at the Second Year of MTs SA Miftahul HudaPabelan,Semarang Regency 2011/2012. Published Thesis. English Department Of Educational Faculty State,Islamic Studies Institute (Stain), Salatiga.

Hatcah, E \& Farhady, H. (1982). Research Design \& Statistics for Applied. Lingusitics. Tehran: Rahnama Publications.

Harmer, J . (2007). How to Teach English. Harlow, CM: Pearson Education Limited.

Nally, F.(2015). Primary Debating Handbook. Schools Programme Officer, Concern Worldwide.

Rubiati, R. (2010). Research of Improving Students' Speaking Skill Through Debate Technique ( A Classroom Action Research with Firts Semester Students of English Language Teaching Departement Tarbiyah Faculty at IAIN Walisongo Semarang in the Academic Year of 2010/2011). Published Thesis. Semarang: Walisongo State Institute for Islamic Studies.

Ryoko, A. (2015). The Effectiveness Of Debate Technique In Teaching And Learning Speaking Skill (An Experimental Research To The Eighth Grade Students Of SMP N 2 Gondangrejo Karanganyar in 2014/2015 Academic Year). Published Thesis .Teacher Training And Education Faculty Slamet Riyadi University. Surakarta.

Sugiyono. (2010). Metode Penelitian Pendidikan (Pendekatan Kuantitatif, Kualitatif dan $R \& D$. Bandung: Alfabeta. 
Somjai, S., \& Jansem, A. (2005). Research of The Use of Debate Technique to Develop Speaking Ability of Grade Ten Students at Bodindecha (Sing Singhaseni) School.Published Thesis. Bangkok:Srinakarinwirot University, International Journal of Technical Research and Applications.

The International Debate Education Association (IDEA). (2010). Debate Formats and Styles. Retrived 9 Januari 2017, from https://idebate.org/debate-formatsstyles.

Schwartz, M. (2003). Discussion as a Teaching Technique. Retrived 10 December 2017, from http://www.ryerson.ca/lt/taga/index.html

Varron. (2016). Types of Debate. Retrived 9 January 2017, from http://varron.expertscolumn.com/article/four-common-types-debates.

Wesson. C. F., (2005). Thesis of the Communication and Influence of Confidence and Uncertainty. Published Thesis. University of Wolverhampton.

Yates, L \& Chisari, M. (2013). Act Sheet 1: Building Confidence In The Language Classroom. Macquarie University.

Zare, P \& Othman, M. (2014). Students' Perceptions toward Using Classroom Debate to Develop Critical Thinking and Oral Communication Ability. Published Thesis. Department of Language and Humanities Education, Faculty of Educational Studies, Universiti Putra Malaysia, Selangor, Malaysia. 